\title{
ULAON PARBOGASONALAP JUALETNIK BATAK TOBA: KAJIAN ANALISIS WACANA KRITIS
}

\section{Mita Nasrani, Jekmen Sinulingga}

Universitas Sumatera Utara

Email:mitaaja2019@gmail.com,jekmen@usu.ac.id

\begin{abstract}
Abstrak
Penelitian ini bertujuan untuk mendeskripsikan ulaon parbogason alap jual Etnik Batak Toba. Teori yang digunakan untuk menganalisis data penelitian ini adalah teori analisis wacana kritis yang dikemukakan oleh Norman Fairclough. Metode yang digunakan dalam penelitian ini adalah metode deskriptif. Adapun hasil yang diperoleh dari penelitian ini yaitu perubahan dalam ulaon parbogason alap jual mencakup perubahan tahapan ulaon parbogason alap jual, tahapan tersebut antara lain, wacana yang berubah dalam ulaon parbogason alap jual adalah wacana marhata sinamot, faktor yang menyebabkan perubahan tersebut adalah: faktor sosial, status sosial, faktor ekonomi, agama dan perkembangan zaman. Dampak dari perubahan ini memiliki dua dampak yaitu dampak positif dan dampak negatif. Dampak Positif Upacara ulaon parbogason alap jual ini terlihat lebih mewahdan juga indah sedangkan dampak negatifnya ulaon parbogason alap jual ini sudah tidak asli lagi karena perkembangan zaman sudah semakin maju, solusi upaya yang dilakukan. Kesimpulan dari penelitian ulaon parbogason alap jual ini adalah bahwa ulaon parbogason alap jual ini sudah ada terjadi perubahan, bergeser, bertambah, dan berkurang. Baik dari segi bahasa, musik, parhobas, marhusip, dan mangaririt
\end{abstract}

Kata Kunci: Ulaon Parbogason, Wacana Kritis, Kajian Analisis

\section{Absract}

This study aims to describe the ulaon parbogason selling Toba Batak ethnic. The theory used to analyze the research data is the theory of critical discourse analysis proposed by Norman Fairclough. The method used in this research is descriptive method. The results obtained from this study are changes in the parbogason, changes in the stages of selling parbogason, parbogason stages include these selling parbogason including: social factors, social status, economic factors, religion and the times. The impact of this change has two impacts, namely a positive impact and a negative impact. The positive impact of selling parbogason ulaon looks more luxurious and beautiful, while the negative impact selling parbogason ulaon ceremony is that it is no longer original because the times are getting more advanced, the solutions are the efforts made. The conclusion from this research on selling parbogason ulaon parbogason that 
is there have been changes, shifts, increases, and decreases. Both in terms of language, music, parhobas, marhusip, and mangaririt Keywords: Ulaon Parbogason, Critical Discourse, Analytical Study

Diserahkan: 03-01-2022Ｄiterima: 25-01-2022Ｄiterbitkan: 20-02-2022

\section{Pendahuluan}

Etnik Batak Toba memiliki upacara seperti pernikahan, kelahiran, hingga kematian. Dan itu masih secara garis besar nya saja. Upacara penikahan masih terbagi menjadi 3 jenis pernikahan dalam etnik Batak Toba. Adapun jenis-jenis pernikahan yang 1) Ulaon Parbogason Alap Jual, 2) Ulaon Parbogason sulang-sulang ni pahopu, 3) Ulaon Parbogason pamasumasu huria (Sibarani, 2012).

Dalam konteks ini penulis mengkaji tentang perubahan, pergeseran, bertambah, dan berkurang. Yang terjadi dalam upacara adat pernikahan etnik Batak Toba yang disebut dengan Ulaon Parbogason Alap Jual. Adapun lokasi penelitian Ulaon Parbogason Alap Jual ini di lakukan di Desa Sabungan ni Huta Kecamatan Ronggur ni Huta (Andriyani, 2018).

Etnik Toba memaknai ulaon parbogason alap jual adalah kegiatan upacara adat sebagai hal yang sangat sakral. Karena dalam melaksanakan sebuah upacara adat ulaon parbogason alap jual tidak bisa dilakukan secara suka-suka, melainkan memiliki tata cara aturan dan juga mempunyai Makna. Ulaon parbogason alap jual ini juga tidak hanya menyangkut laki-laki dan perempuan saja, tetapi juga keluarga kedua mempelai juga salah satu bagian penting dalam melakukan ulaon parbogason alap jual (Ambarita et al., n.d.).

Menurut Swita, tujuan perkawinan bagi Etnik Batak Toba adalah mendapatkan anak laki-laki yang sah. Hal ini dilakukan karena laki-laki akan menjadi penerus marga ayahnya. Menurut Fairclough dan Wodak analisis wacana kritis melihat wacana pemakaian bahasa dalam tuturan dan tulisan-sebagai bentuk dari praktik social (Eriyanto, 2001).

Wacana kemudian dimaknai sebagai satu-kesatuan teks dalam konteks secara bersama-sama berubah, bergeser, bertambah, serta berkurang. Analisis wacana memfokuskan pada struktur yang secara alamiah terdapat pada bahasa lisan, sebagaimana banyak terdapat dalam wacana seperti percakapan, wawancara, komentar, dan ucapan-ucapan (Simbolon, 2020). Dari pendapat para ahli diatas maka penulis menyimpulkan bahwa Analisis wacana kritis adalah penggunaan bahasa dalam komunikasi dapat dilakukan secara tulisan dan lisan, seperti debat, tanya jawab, surat, dan juga makalah (Simanjuntak, 2006).

Berdasarkan penjelasan tersebut, hal ini merupakan persoalan yang menarik perhatian penulis untuk meneliti Ulaon Parbogason alap jual Etnik BatakToba: Kajian Analisis Wacana Kritis. Karena ada unsur wacana yang berubah, bergeser, bertambah, serta berkurang (Munfarida, 2014). Hal ini dipengaruhi oleh semakin majunya dan perkembangan teknologi sehingga menyebabkan nilai-nilai yang sudah ditanamkan dari 
dulu oleh nenek moyang menjadi goyah karena masuknya nilai-nilai dari luar (Umanailo et al., 2016). Untuk mengetahui informasi tersebut maka peneliti ingin melihat secara spesifik perubahan dan pergeseran yang terjadi pada wacana adat ulaon parbogason alap jual.

Tujuan Penelitiaan ini adalah mendeskripsikan perubahan dalam wacana, perubahan dalam tahapan pada upacara adat, dampak perubahan, dan solusi dalam ulaon parbogason alap jual etnik Batak Toba. Manfaat Penelitian ini yakni manfaat teoritis dan manfaat praktis.

\section{Metode Penelitian}

Metode dalam penelitian ini ialah metode deskriptif. Metode deskriptif yaitu penelitian yang berusaha untuk menuturkan pemecahan masalah berdasarkan data-data dan jarak, juga menyajikan data dan menginterpretasikan data (Sugiyono, 2012). Lokasi penelitian yang dipilih penulis adalah Desa Sabungan ni Huta, Kecamatan Ronggur ni Huta, Kabupaten Samosir. Ada 3 hal alasan penulis memilih lokasi penelitian ini sebagai berikut: (1) masih tetap melaksanakan upacara adat ulaon parbogason Alap jual pada etnik Batak Toba. (2) Mudah mencapai lokasi tersebut. (3) Memiliki key informan. Sumber data dari penelitian ini diperoleh dari narasumber (informan) yaitu sebagai sumber data, sumber informasi dari apa yang akan diteliti oleh penulis (Nugrahani \& Hum, 2014).

Instrumen atau alat yang digunakan pada penelitian ini ialah alat yang berisi informasi upacara adat ulaon parbogason alap jual Etnik Batak Toba. Di sisi lain penulis sebagai "human instrument" karena penulis berasal dari Batak Toba. Metode pengumpulan data untuk mendapatkan data yang sesuai dengan masalah penelitian ini, maka pengumpulan atau dilakukan dengan tiga cara yaitu Metode observai partisipatoris langsung, metode wawancara, metode Pustaka (Mustari \& Rahman, 2012).

Metode analisis data adalah metode atau cara dalam mengelola data yang mentah, sehingga menjadi data yang cermat atau akurat dan ilmiah" (Hutasoit et al., 2012). Dalam konteks ini analisis adalah kegiatan untuk memanfaatkan data sehingga dapat diperoleh kebenaran objek dan teori. Dalam menganalisis penulis dituntut untuk memiliki nalar dan kreativitas yang tinggi sehingga data yang dianalisis akurat, serta kebenarannya mampu dipertanggung jawabkan. Menganalisis data merupakan suatu langkah yang sangat kritis dalam penelitian, karena tahap dalam menyelesaikan masalah ialah menganalisis. Untuk menganalisis data penelitian ini, maka penulis menggunakan metode deskriptif.

\section{Hasil dan Pembahasan}

\section{Wacana Zaman Dahulu}

Ditingki na marhusip, nunga putus hian jambar ni suhut rupani Rp. 30.000,jala nunga dipaboa suhut paranak dohot parboru hian i tu pandehatana be asa dipaboa angka pandehata inon $i$ tu angka sisuruonna mandok "taoranna" di tingki na manggigil manang mangelek jambar. Artinya: di waktu berbisik-bisik sudah diputuskan 
bagian dari suhut yaitu Rp. 30.000, dan sudah disampaikan pihak laki-laki dan pihak perempuan sebelumnya itu ke raja parhata masing-masing supaya disampaikan raja parhata itu kepada yang diperintahkannya mengatakan diantarkan di waktu yang panas atau membujuk bagian.

Parboru: "Mangkatai ma hita, amang raja ni parboruonnami! Sai jolo minangnang do ninna asa ninungnung, sai jolo pinangan do asa sinungkun. Ba nunga hupangan hami antong sipanganon na binoanmuna i. Jagar do hami bosur manganhon indahan $n$ alas $i$, jangar hami sagat manganhon juhut na tabo $i$, huhut sobu minum tuak tangkasan na tinahumuna $i$, jadi ba:

\section{Dia ma nuaeng langkatna, dia ma unokna:}

\section{Dia ma hatana, dia nidokna}

Artinya: bicaralah kita amang rajanami parboruannami, lebih dulu dimakanlah baru ditanya. Ya sudah kami makan makanan yang kalian bawa. Cukup kenyang kami memakan nasi yang panas, cukup puas kami makan daging yang enak, serta meminum tuak asli yang kalian tuangkan itu.

jadi begitulah:

Apalah sekarang kulitnya, dimana bagiannya:

Apalah katanya, apa yang dikatakannya

Paranak: Gabe ma jala horas Rajanami!

Taringot di sipanganon $i$ :

Sititi ma sihompa, golang-golang pangarahutna:

Tung so sadia pe i nuaeng na hupatupa hami I, sai godang ma pinasuna

Artinya: subur dan sehatlah rajanami! Teringat pada makanan itu:

Sititi adalah sihompa, gelang-gelang pengikatnya:

Walau tak seberapa sajian yang kami sediakan, semoga berkahnya melimpah

"Sai manumpak ma tondimuna Rajanami, marhitehite tangiangmuna di hami parboruonmuna on, sai lam tamba sinadongan di hami, asa tarpatupa hami dope nian na tumabo sian on laho pasangaphon hamu hula-hulanami. Jadi ianggo taringot dilapatan ni sipanganon ni sipanungkunmuna i Raja name, ba panggabean parhorasan do nidokna. Boti ma da Rajanami!"

Artinya: supaya membantulah roh kalian rajanami, melalui doa kalian bagi kami pihak perempuan kalian ini, semoga semakin bertambahlah rezeki sama kami, supaya kami dapat menyediakan kembali yang lebih enak dari ini untuk menghormati kalian hula-hula kami. Jadi teringat artinya makanan yang kalian tanya itu raja kami, ya semoga menjadi sejahteralah yang dikatakannya. Begitulah raja kami!"

Parboru: Gabe ma tutu horas Raja ni parboruon! Sai sahat hata na uli, hata na denggan nanidokmuna i tumpahon ni Amanta Debata. Sai dapot nian songon hata ni umpasa

:Artinya: Sejahteralah lah raja ni parboruon! Semoga kata-kata yang indah dan baik yang kalian katakan itu diberikan Tuhan.semoga dapat seperti kata pepatah: 
Bona ni aek puli dolok ni sitopanganSai tubu ma di hamu angka na uli, jala sai lam tamba mapansamotan.

Artinya: pangkal air puli bukit yang ditopang Semoga lahirlah kepada kalian semua yang baik, dan semoga semakin bertambahlah kekayaan

\section{Wacana Masa Kini}

Parboru : Jadi ahama roha haroromuna tu bagas name

Perempuan : Jadi apalah maksud kedatangan kalian ke rumah kami

Paranak : Mamboan sipanganon holan lao mangan sarampak

Laki-laki : Kami datang bawa makanan hanya untuk makan bersama

Perempuan: Apa maksud Kalian kesini? kalian kasih kami makan enak, kalian kasih kami makan daging. Apa lah maksud kedatangan kalian kesini?

Parboru : Aha roha muna tuson? Hamu mangalean hami mangallangna tabo hamu mangalean hami mangallang juhut. Ahama rohaharoromuna tuson?

Paranak : Ia hami mangalehon mangan asa mangan sarampak do

Laki-Laki : Ya kami kasih makan biar makan bersama saja

Parboru : Bona ni aek puli dolok ni sitopanganSai tubu ma di hamu angka na uli, jala sai lam tamba mapansamotan

pangkal air puli bukit Artinya: yang ditopang Semoga lahirlah kepada kalian semua yang baik, dan semoga semakin bertambahlah kekayaan

alai sasintongna roha dohot tahi muna?

Paranak : Sasintongnya roha dohot tahi haroronami tuson ima anak nami dohot boru muna nunga adong sangkap lao marbagas, hami naeng manungkun didiama hita laho mambahen adat na

Laki-laki : Sebenarnya maksud dan tujuan kedatangan kami kesini adalah anak kami dan boru kalian sudah ada rencana untuk menikah, kami mau menanyakan dimanalah kita akan buat adatnya

Parboru : Ohh molo songoni do, nunga sonang roha nami mambege $i$. hami nunga saroha lao manjalo sangkap muna naeng lao marhata sinamot. Jadi dokkon hamuma aha na naeng hamu lehon dohot sadiama naeng hamu lehon?

Perempuan : Ooh kalau kayak gitunya, sudah jelas senang hati kami mendengar nya. Kami sudah sepakat untuk menerima rencana kalian mau marhata sinamot. Jadi katakan kalianlah apa yang ingin kalian kasih dan berpalah mau kalian kasih?

Paranak : Mauliate amangboru, mauliate hula-hula, tutu ma hamu anak ni raja. Molo boi sahali mandokkonma hami, ni on ma horbo na, ni on ma hoda na, na lapatanna hami dokkon pe sinamot nasai alai inon ma lao tu 
sudena, naeng tulang pe annongan magidohon sian $i$ ma dibuat, naeng lao motor pe tu uduran tondong pe sian i ma dibuat sudena, i ma sudena

\section{Madek-dek ansosoittongon tu tumbara}

\section{Unangdok hamu hami parholit}

Laki-laki : Terimakasihlah amangboru, terimakasih hula-hula, benarlah kalian anak raja. Kalau bisa sekali membilang lah kami, itu lah kerbaunya, itulah kudanya yang artinya kami bilangpun sinamot sekian tapi itulah untuk semua mau Tulang pun nanti minta sesuatu dari situlah diambil, mau kendaraan mobil untuk tamu rombonganpun disitu juga di ambil pokoknya disitulah semua. Jatuhlah ansosoit tepat ke tumbara jangan kalian bilang kami pelit.

Parboru : Denggan ma hami satolop, jadi sadiama lehonon muna?

Perempuan : Baiklah kami setuju, jadi berapalah kalian kasih?

Paranak : Rp. 50.000.000 lobina lima juta na i naeng dilehon di tingki ari pestana

Laki-laki : $\operatorname{Rp}$ 50.000.000, (sisanya lima juta lagi akan dikasih waktu hari pestanya)

Parboru : Sadiama na naeng lehonon muna tu hami saonari? Alana porluma hepeng lao tu dalan, naeng lehon tu tulang, dohot naringkotna asingna.

Perempuan : Berapa lah mau kalian kasih ke kami sekarang? karena kan perlunya uang untuk jalan, mau kasih ke Tulang, dan keperluan lainnya.

Dari kedua wacana di atas wacana zaman dulu lebih sering menggunakan umpasa pada saat penyampaian pembicaraan menggunakan umpasa, sedangkan wacana dimasa sekarang ini umpasa tersebut masih tetap untuk dilakukan tapi sudah jarang, umpasa itu diakukan pada waktu awal pembicaraan saja dan akhir.

\section{Tahapan Upacara Ulaon Parbogason Alap Jual Etnik Batak Toba \\ Upacara Adat Ulaon Parbogason Alap Jual etnik Batak Toba memiliki tujuh tahapan adapun tahapan upacara Ulaon Parbogason Alap jual sebagai berikut:}

\section{Mangaririt}

Mangaririt berasal dari kata ririt yang berarti pilih. Jadi mangaririt berarti memilih calon pasangan hidup yang artinya laki-laki akan pergi dari rumahnya atau keluar dari kampungnya untuk mendatangi si gadis (Sinaga, Richard, 2012).

\section{Marhori-hori dinding}

Adalah Pembicaraan kesepakatan kedua belah pihak antara orang tua laki-laki dan perempuan namun masih pembicaraan antara kedua orang tua saja, belum turut membawa dalihan natolunya mereka masing-masing.

\section{Marhusip}

Marhusip itu adalah tahapan lanjutan dari mangaririt, jadi kalau sebelumnya berdasarkan keterangan diatas mangaririt itu disebut memilih sedangkan marhusip adalah perkenalan antara kedua belah pihak silaki-laki dan siperempuan menyampaikan 
kepada orang tua mereka masing-masing untuk memberi tahu bahwa sudah ada rencana mereka kerana yang lebih serius lagi atau bisa disebut dengan menikah. Dan setelah laki-laki memberi tahu kepada orang tua nya maka orang tua laki-laki mendatang tempat perempuan sambil membawa dongan tubu mereka untuk membicarakan sinamot calon istri anaknya

\section{Marhata Sinamot}

Adalah salah satu dari rangkaian ulaon adat yang sangat penting yang dihadiri untuk dalihan natolu pihak paranak dan parboru untuk membicarakan mahar atau sinamot dari putri yang akan menikah yang harus dibayar pihak paranak kepada pihak parboru juga penentuan jumlah ulos, parjuhut (hewan yang akan dipotong) waktu dan tempat serta jumlah undangan.

\section{Martumpol}

Martumpol adalah bagian dari salah satu tahap Ulaon Parbogason Alap jual tapi martumpol bukanlah bagian dari adat Ulaon Parbogason Alap jual namun walupun begitu martumpol juga hal yang wajib untuk dilakukan, karena martumpol itu adalah kegiatan dari gereja dan bisa dibilang juga sebagai pra nikah atau gambaran ucapan janji suci di altar pada saat di hari pernikahan mereka nanti.

\section{Martonggo Raja}

Adalah sebuah kegiatan yang dilakukan di tempat laki-laki dan dihadiri oleh dongan tubu, dongan sahuta, boru, bere. Dan martonggo raja ini biasanya dilakukan pada saat semingu sebelum hari pesta.

\section{Manjalo Pasu-Pasu}

Adalah pemberkataan di gereja, pengantin harus mengucap janji suci mereka di atas altar jadi pernikahan etnik Batak Toba ini sebelum memasuki gedung untuk melaksanakan upacara pernikahan, maka pihak pengantin dan seluruh keluarga harus memasuki gereja terlebih dahulu, supaya diberkati pastor atau pendeta. 
4. Bentuk Perubahan tahapan wacana yang ditemukan dalam ulaon parbogason alap jual Etnik Batak Toba

\begin{tabular}{|c|c|c|c|c|c|c|}
\hline \multirow[t]{3}{*}{ NO } & \multirow[t]{3}{*}{ BENTUK } & \multicolumn{5}{|c|}{ DINAMIKA (PERUBAHAN) } \\
\hline & & \multirow[t]{2}{*}{ DULU } & \multirow[t]{2}{*}{ SEKARANG } & \multicolumn{2}{|c|}{ DAMPAK } & \multirow[t]{2}{*}{ SOLUSI } \\
\hline & & & & POSITIF & NEGTIF & \\
\hline 1 & Mangaririt & $\begin{array}{l}\text { Masa dulu itu mangaririt } \\
\text { kedua orang tua laki-laki } \\
\text { dan perempuan } \\
\text { melakukan perjodoan } \\
\text { antar anak mereka . Jadi } \\
\text { kedua keluarga belah } \\
\text { pihak tersebut akan } \\
\text { mempertemukan anak } \\
\text { mereka masing-masing } \\
\text { untuk berkenalan awal } \\
\text { dan berlanjut } \\
\text { keperjodohan }\end{array}$ & $\begin{array}{lr}\text { Untuk masa } & \text { sekarang } \\
\text { ini perjodoan } & \text { sudah } \\
\text { jarang } & \text { untuk } \\
\text { ditemukan, } & \text { karena } \\
\text { semakin } & \text { majunya } \\
\text { teknologi dan } & \text { luasnya } \\
\text { pergaulan membuat } \\
\text { para muda-mudi lebih } \\
\text { mandiri } \\
\text { pasangan } \\
\text { mereka. }\end{array}$ & $\begin{array}{lr}\text { Pasangan } & \text { muda- } \\
\text { mudi jadi lebih } & \text { untuk } \\
\text { gampang } & \text { ungan } \\
\text { mencari } & \text { pasangan } \\
\text { hidup mereka } \\
\text { bahkan ada yang } \\
\text { menikah dengan } \\
\text { warga negara } \\
\text { asing, ataupun } \\
\text { dengan etnik lain } \\
\text { yang tidak beretnik } \\
\text { Batak }\end{array}$ & $\begin{array}{l}\text { Pasangan muda-mudi } \\
\text { lebih banyak terjun ke } \\
\text { pergaulan bebas, } \\
\text { mengakibatkan masa } \\
\text { depan generasi muda- } \\
\text { mudi menjadi rusak. }\end{array}$ & $\begin{array}{l}\text { Diera zaman sekarang ini teknologi } \\
\text { sangatlah membantu baik itu dalam } \\
\text { kinerja maupun komunikasih. } \\
\text { Sebaiknya generasi muda-mudi } \\
\text { harus lebih bijak lagi dalam } \\
\text { menggunakan teknologi, supaya } \\
\text { tidak jatuh kedalam pergaulan } \\
\text { bebas. }\end{array}$ \\
\hline 2 & $\begin{array}{l}\text { Marhorihori } \\
\text { dinding }\end{array}$ & $\begin{array}{l}\text { Pada masa dulu marhori- } \\
\text { hori dinding masih suatu } \\
\text { hal yang wajib untuk } \\
\text { dilakukan. Namun } \\
\text { pembicaraan ini belum } \\
\text { turut mebawa masing- } \\
\text { masing dalihan natolu } \\
\text { tapi masih para kedua } \\
\text { orang tua mempelai saja } \\
\text { yang berkomunikasih. }\end{array}$ & $\begin{array}{l}\text { Di masa sekarang ini } \\
\text { marhori-hori dinding } \\
\text { ini sudah tidak suatu } \\
\text { hal yang wajib lagi } \\
\text { untuk dilaksanakan. } \\
\text { Kalaupun marhori-hori } \\
\text { dinding ini tetap ingin } \\
\text { dilakukan sudah bisa } \\
\text { dengan cara melalui } \\
\text { telepon tidak harus }\end{array}$ & $\begin{array}{l}\text { Tidak makan } \\
\text { waktu, dan dapat } \\
\text { mempercepat } \\
\text { proses tahapan } \\
\text { ulaon parbogason } \\
\text { alap jual }\end{array}$ & $\begin{array}{l}\text { Kurangnya saling } \\
\text { mengenal antara } \\
\text { keluarga laki-laki dan } \\
\text { perempuan sehingga } \\
\text { mengakibatkan } \\
\text { kurangnya terjadi } \\
\text { kekompakan antar } \\
\text { kedua mempelai } \\
\text { keluarga tersebut. }\end{array}$ & $\begin{array}{l}\text { Sebaiknya kedua calon pengantin } \\
\text { sebelum beberapa bulan yang akan } \\
\text { pesta. Kedua calon pengantin ini } \\
\text { sudah saling mengasih tau orang } \\
\text { Tua masing-masing, bahwa sudah } \\
\text { ada rencana menikah sehingga } \\
\text { kedua calon yang akan berbesan } \\
\text { bisa melakukan pendekatan dan } \\
\text { perkenalan yang lebih dalam satu } \\
\text { sama lain. }\end{array}$ \\
\hline
\end{tabular}


bertatap muka lagi. Hal ini bisa terjadi karena ada jarak tempat yang jauh misalkan orang tua laki-laki dan perempuan beda kota.

\begin{tabular}{|c|c|c|c|c|c|c|}
\hline 3 & Marhusip & $\begin{array}{l}\text { Berdasarkan penelitian } \\
\text { marhusip untuk zaman } \\
\text { dulu tidak ada }\end{array}$ & $\begin{array}{lr}\text { Masa sekarang } \\
\text { marhusip sudah ada } \\
\text { dan wajib untuk } \\
\text { dilakukan }\end{array}$ & $\begin{array}{lr}\text { Dengan } & \text { adanya } \\
\text { tahapan } & \text { dari } \\
\text { marhusip } & \text { ini } \\
\text { tingkat kegagalan } \\
\text { untuk } \quad \text { menikah } \\
\text { berkurang } & \text { karena } \\
\text { sudah } & \text { ada } \\
\text { pembicaraan } \\
\text { kesepakatan yang } \\
\text { dihadiri } \\
\text { dalihan natolunya } \\
\text { masing-masing. }\end{array}$ & $\begin{array}{l}\text { Dengan tidak adanya } \\
\text { marhusip pada zaman } \\
\text { dulu maka pernikahan } \\
\text { itu bisa gagal karena } \\
\text { adanya } \\
\text { pahaman kesalah } \\
\text { pembicaraan atau beda } \\
\text { pendapat antar kedua } \\
\text { belah pihak keluarga. }\end{array}$ & 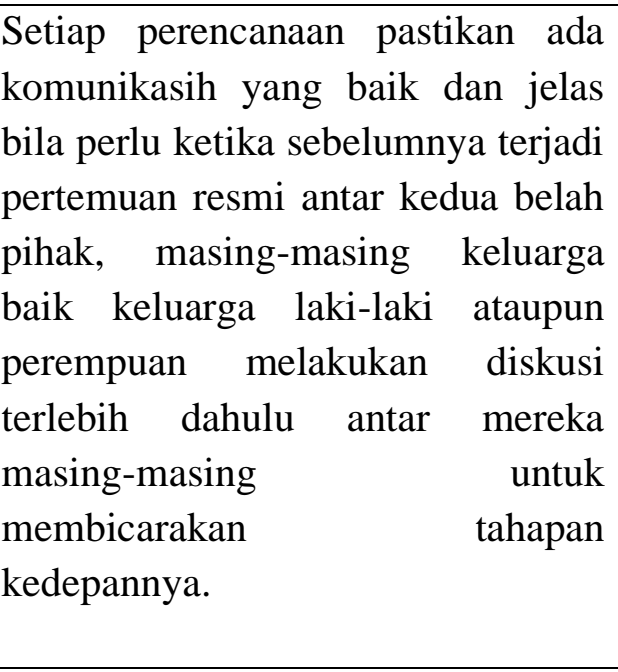 \\
\hline 4 & $\begin{array}{l}\text { Marhaata } \\
\text { Sinamot }\end{array}$ & $\begin{array}{l}\text { Tingkat kegagalan dalam } \\
\text { marhata sinamot itu bisa } \\
\text { gagal karena pada masa } \\
\text { dulu belum ada namanya } \\
\text { tahapan marhusip }\end{array}$ & $\begin{array}{l}\text { Sejak adanya tahapan } \\
\text { marhusip ini tigkat } \\
\text { kegagalan } \\
\text { marhata sinamot ini } \\
\text { kecil kemungkinan } \\
\text { untuk terjadi }\end{array}$ & $\begin{array}{l}\text { Tingkat kegagalan } \\
\text { untuk menikah } \\
\text { kecil kemungkinan } \\
\text { untuk terjadi }\end{array}$ & $\begin{array}{l}\text { Anak perempuan } \\
\text { sebagai boru itu } \\
\text { kesannya seperti dijual } \\
\text { dengan jumlah uang } \\
\text { yang sudah disepakati } \\
\text { keluarga pihak laki- } \\
\text { laki dan perempuan }\end{array}$ & $\begin{array}{l}\text { Segala sesuatunya patut untuk } \\
\text { dibicarakan antara keluarga inti } \\
\text { terlebih dahulu dan mempunyai } \\
\text { komunikasih yang baik dan benar. }\end{array}$ \\
\hline
\end{tabular}


Mita Nasrani, Jekmen Sinulingga

\begin{tabular}{|c|c|c|}
\hline 5 & Martumpol & $\begin{array}{l}\text { Ditahapan martumpol ini } \\
\text { belum ada terjadinya } \\
\text { perubahan, proses } \\
\text { martumpol pada masa } \\
\text { dulu dan masa sekarang } \\
\text { masih sama belum ada } \\
\text { terjadi bergeser, } \\
\text { bertambah dan berkurang }\end{array}$ \\
\hline 6 & $\begin{array}{c}\text { Martonggo } \\
\text { Raja }\end{array}$ & \begin{tabular}{lr} 
Ditahapan & \multicolumn{2}{r}{ martonggo } \\
raja ini juga masih \\
belum ada terjadinya \\
perubahan, & proses \\
martonggo raja pada \\
masa dulu dan masa \\
sekarang masih sama \\
belum ada terjadi \\
bergeser, bertambah dan \\
berkurang
\end{tabular} \\
\hline
\end{tabular}




$\begin{array}{llll}\text { Manjalo } & \text { Berdasarkan penelitian } & \text { Berdasarkan penelitian Pasu-pasu sudah Untuk } & \text { tahapan } \\ \text { pasu-pasu } & \text { zaman dahulu pasu-pasu } & \text { dizaman sekarang dilakukan lebih manjalo pasu-pasu ini } \\ & \text { dan pemberkatan itu } & \text { pasu-pasu itu tidak baik lagi dan kalau dari segi negatif } \\ & \text { dapat dilakukan di dalam dapat dilakukan lagi diberkati } & \text { oleh berdasarkan penelitian } \\ & \text { rumah dan diberkati oleh dengan hanya diberkati pendeta ketika penulis } & \text { tidak } \\ & \text { orang yang dituakan di } & \text { oleh orang yang dipandang dengan menemukan dampak } \\ & \text { kampung itu. } & \text { dituakan di kampung secara agama dan negatif nya karena } \\ & \text { melainkan sudah harus negara pun sudah manjalo pasu-pasu ini } \\ & \text { dilakukan di dalam sah. } & \text { adalah proses untuk } \\ & \text { geeja dan diberkati } & \text { pemberkatan di dalam } \\ & \text { dengan pendeta } & \text { gereja }\end{array}$

Ada 5 perubahan yang terjadi dalam tahapan ini, yaitu Mangaririt, Marhori-hori dinding, Marhusip, Marhata Sinamot, dan Manjalo Pasupasu. Sedangkan Martumpol dan juga Martonggo Raja belum ada proses pelaksanaannya masih sama belum ada terjadi bergeser, berkurang, maupun bertambah baik pada masa dulu dan masa sekarang. 


\section{Faktor yang mempengaruhi perubahan yang terjadi dalam Tahapan Upacara Adat Ulaon ParbogasonAlap Jual Etnik Batak Toba}

A. Faktor Sosial

Dizaman dulu teknologi belum ada sehingga masyarakat melakukan aktifitas secara manual dengan seiringnya waktu berjalan zaman sudah mulai maju dan bahkan untuk sekarang ini teknologi berkembang pesat. Hal itu membuat masyarakat mulai beralih ke teknologi karena seiringnya zaman semakin maju dan teknologi sudah semakin berkembang pesat. Adapun tujuan dari perubahan teknologi ini untuk memudahkan masyarakat mempermudah pekerjaannya, sebagaimana seperti kita ketahui pada zaman dulu masyarakat masih memakai alat-alat musik yang tradisional dan hal itu membuat orang melakukan inovasi dengan menciptakan alat-alat musik supaya membuat suasana pesta yang tadinya sunyi menjadi meriah dan hidup dengan adanya alat musik tersebut.

\section{B. Status Sosial}

Status sosial dan gaya hidup. Hal ini dapat untuk dilihat bagaimana perubahan dari ulaon parbogason zaman dulu ke zaman sekarang. Kalau zaman dulu ulaon parbogason alap jual itu hanya sebatas memakai terpal, tikar dan tempatnya pun masih dilakukan di halaman rumah, dan para tamu yang menghadiri pun masih orang-orang yang kalangan biasa saja. dizaman sekarang ini sudah banyak terjadi perubahan misalkan, dari segi tempat zaman sekarang ini masyarakata Batak Toba melakukan ulaon parbogason alap jual sudah di dalam gedung lengkap dengan memakai jasa wedding organizer, persiapan untuk makanan pun sudah memakai jasa cathring, dan para tamu undangan juga dihadiri oleh seluruh lapisan masyrakat baik dari lapisan masyrakat bawah, menengah dan atas.

\section{Faktor Ekonomi}

Zaman dulu ulaon parbagoson alap jual masih dilakukan secara sederhana dengan cara dilakukan pasu-pasu raja saja pernikahan itu dulunya. kenapa hanya dilakukan dengan dipasu-pasu raja adat saja karena dulu kondisi ekonomi dari pihak paranak belum mencukupi untuk melakukan pernikahan secara adat penuh. Tetapi seiringnya berkembangnya zaman pernikahan tersebut telah mengalami perubahan di mana dulunya pernikahan itu dulu hanya dilakukan dengan cara pasu-pasu raja, sekarang berubah menjadi pernikahan yang sudah diberkati di gereja dan sekaligus langsung melaksanakan adat secara penuh. Karena seiringnya berkembangnya zaman perekonomian sudah mengalami perubahan dengan banyaknya mata pencarian di zaman sekarang, sehingga penikahan zaman sekarang telah mengalami perubahan menjadi lebih baik lagi.

D. Agama

Zaman dulu orang belum ada namanya mempercayai agama dan kepercayaan pun masih dilakukan secara mistis atau penyembahan berhala, tapi tidak dengan zaman sekarang ini orang sudah beralih kepecayaan Agama. Orang zaman dulu melakukan ulaon parbogason alap jual hanya di pasu-pasu dengan raja adat saja tapi tidak lagi 
dizaman sekarang orang melakukan ulaon parbogson alap jual sudah di berkati pendeta di gereja.

E. Perkembangan zaman yang semakin

Maju

Perkembangan zaman yang semakin pesat membuat semua berubah. Contoh dari segi penampilan, kalau dulu masyrakat Batak Toba kalau melakukan ulaon parbogason alap jual hanya menggunakan pakaian seadaanya pengantin memakai kain ulos, di zaman sekarang ini pakaian-pakaian sudah banyak yang menarik. Zaman sekarang masyarakat BatakToba melakukan pesta atau menghadiri pesta sudah menggunakan kebaya yang bermodel serta memakai pernak pernik yang dikenakan dipakaian itu, sehingga menghasilkan penampilan yang bagus.

\section{Dampak perubahan wacana dan solusi dalam Ulaon Parbogason Alap Jual Etnik Batak Toba \\ Dampak}

Adapun dampak dari perubanahn ini antara lain:

1) Dampak Positif:

a. Adat Batak pun masih bisa tetap dapat dilaksanakan walaupun tidak seperti dulu lagi. yang dalam arti ulaon parbogason alap jual itu bisa mengikuti perkembangan zaman tapi tetap dalam pantauan, walaupun sudah banyak terjadi berubah dan bergeser dizaman sekarang ini, namun walaupun begitu format dan inti dari ulaon parbogason alap jual itu jangan sampai dihilangkan, sehingga budaya adat Batak ulaon parbogason alap jual ini tidak melenceng atau tidak terjadi seperti hal yang tidak diinginkan.

b. Pelakasanaan ulaon parbogason alap jual lebih simple

c. Lebih kelihatan mewah

2). Dampak Negatif:

a. Adat Batak ini lama-lama akan bisa hilang

b. Adat batak itu sudah tidak asli lagi karena faktor perkembangan zaman

c. Rasa kekeluargaannya semakin terkikis, karena pihak parhobas sudah tidak sesibuk dulu lagi.

d. Kurang nya pengetahuan tentang ulaon parbogason Alap Jual

\section{Solusi}

Pemda (Pemerintah daerah)

a. Pemerintah daerah ikut berpartisipasi dan mendukung memberi fasilitas kepada masyarakat untuk melestarikan budaya ulaon parbogason alap jual dan menyimpannya dalam bentuk digital

b. Pemerintah daerah ikut berkontribusi dalam memberikan biayaya untuk mendukung pagelaran festifal budaya dengan tujuan untuk memperkenakan budaya-budaya dapat dikenal masyrakat lokal maupun international

Tokoh Adat 
a. sebagai etnik Batak Toba generasi muda atau orang tua saling bekerja samauntuk

kompak melestarikan budaya, dengan cara memperkenalkan ke masyarakat melalui media

b. Sering melakukan forum diskusi untuk membicarakan mengenai adat Batak Toba

c. Adat Batak Toba ini harus beradaptasi dengan lingkungan yang artinya bisa mengikuti kesepakatan tapi jangan sampai lari dari inti

d. Orang Tua harus merunkan atau memperkenalkan budaya batak ke anak nya atau

generasi muda.

Tokoh Agama

a. Tokoh agama tidak menilai adat itu suatu hal yang negatife

b. Sebaiknya Tokoh Agama mendukug pelaksanaan adat istiadat selama itu mengandung nilai yang baik

Ekonomi

a. Mengembalikan makna sebenarnya dari sinamot dan memberi pemahaman kepada kaum muda bahwa tidak ada harga jual untuk manusia yang dikatakan tuhor ni boru

b. Menjalankan kembali makna dari setiap tahapan dari ulaon parbogason alap jual etnik Batak Toba agar tidak terjadi kesalahan dalam praktek dan merugikan pihak tertentu khususnya perempuan etnik Batak Toba

\section{Kesimpulan}

Adapun tahapan upacara adat Ulaon ParbogasonAlap Jual Etnik Batak Toba terdiri dari 7 tahap yaitu, (1) Mangaririt, (2) Marhori-hori dinding (3) marhusip, (4) Marhata sinamot, (5) Martonggoraja, (6) Martumpol, (7) Manjalo Pasu-pasu, Secara tahapan ulaon parbogaon alap jual ini sudah ada terjadi perubahan, begeser, bertambah, dan berkurang yang sudah terjadi.

Upacara adat ulaon parbogason alap jual yang dilaksanakan oleh orang tua kita zaman dulu masih asli, namun dimasa sekarang ini ulaon parbogason alap jual ini sudah tidak asli lagi, namun walapun begitu ulaon parbogason alap jual ini saat berlangsung masih tetap dalam garis dalam arti tidak lewat dari inti upacara ulaon parbogason alap jual. 


\section{BIBLIOGRAFI}

Ambarita, G. N., Simanjuntak, H., \& Seli, S. (n.d.). Kajian Semantik Peristilahan Adat Dalam Upacara Perkawinan Batak Toba. Jurnal Pendidikan Dan Pembelajaran Khatulistiwa, 8(7), 360-372. Google Scholar

Andriyani, D. (2018). Erdemu Bayu Etnik Batak Karo Kajian: Wacana Kritis. Google Scholar

Eriyanto. (2001). Analisis wacana: pengantar analisis teks media. LKiS Yogyakarta. Google Scholar

Hutasoit, J. A., Ganguli, S., Siopsis, G., \& Therrien, J. (2012). Strongly coupled striped superconductor with large modulation. Journal of High Energy Physics, 2012(2), 1-21. Google Scholar

Munfarida, E. (2014). Analisis wacana kritis dalam perspektif Norman Fairclough. KOMUNIKA: Jurnal Dakwah Dan Komunikasi, 8(1), 1-19. Google Scholar

Mustari, M., \& Rahman, M. T. (2012). Pengantar metode penelitian. Laksbang Pressindo. Google Scholar

Nugrahani, F., \& Hum, M. (2014). Metode penelitian kualitatif. Solo: Cakra Books, 1(1). Google Scholar

Sibarani, R. (2012). Kearifan lokal: hakikat, peran, dan metode tradisi lisan. Asosiasi Tradisi Lisan (ATL). Google Scholar

Simanjuntak, B. A. (2006). Struktur sosial dan sistem politik Batak Toba hingga 1945: suatu pendekatan antropologi budaya dan politik. Yayasan Pustaka Obor Indonesia. Google Scholar

Simbolon, F. M. S. (2020). Ulaon Parbogason Etnik Batak Toba: Kajian Feminisme”. Google Scholar

Sugiyono. (2012). Metode Penelitian Kuantitatif, Kualitatif, dan R\&D (22nd ed.). Alfabeta CV. Google Scholar

Umanailo, M. C. B., Sos, S., Umanailo, M. C. B., \& Sos, S. (2016). Ilmu sosial budaya dasar. Google Scholar

First publication right:

Jurnal Syntax Fusion: Jurnal Nasional Indonesia

This article is licensed under:

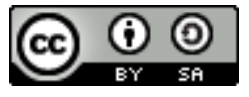

